\title{
Communication
}

[Comunicação]

\section{Incidence of coccidiosis in different rabbit keeping systems}

\author{
[Incidência de coccidiosis em diferentes sistemas de criação de coelhos] \\ P. González-Redondo ${ }^{1}$, A. Finzi ${ }^{2}$, P. Negretti ${ }^{2}$, M. Micci ${ }^{3}$ \\ ${ }^{1}$ Departamento Ciencias Agroforestales-EUITA - Universidad de Sevilla \\ 41013 - Sevilla, Spain \\ ${ }^{2}$ Rabbit Centre - Animal Production Department - University of Tuscia - Viterbo, Italy \\ ${ }^{3}$ Istituto Zooprofilattico Sperimentale delle Regioni Lazio e Toscana - Viterbo, Italy
}

Coccidiosis is considered to be a major parasitic disease that causes considerable economic losses in rabbit farming (Peeters et al., 1988). Hygienic measures and keeping conditions play a determinative role but the use of anticoccidial is generalised and still supported by specific research (Gutiérrez, 2003; Coudert, 2004). However the interest for a possible demedicalization is nowadays increasing (Dalle Zotte, 2002).

The need of helping rabbit keeping in developing countries where production was very impaired by specific climatic, nutritional and environmental conditions and where pharmacological prophylaxis or therapy was impaired by costs, problems of conservation and difficult supply reasons, led to the development of an alternative outdoor keeping system (Finzi, 1987; Finzi et al., 1992a; 1992b). This is based on a sheltering system consisting in an underground explorable cell connected with an external cage (De Lazzer and Finzi, 1992; Finzi et al., 1992b; 2000). It was later found that it was a very appropriate system for maintaining good health conditions when it was applied in Italy, where is widely spread, mainly in the Viterbo province (Finzi, 2004; Finzi et al., 2004). This alternative production system, aimed at producing of high quality meat and developed by the Rabbit and Guinea Pig Unconventional Keeping Experimental Centre in Viterbo since the first $80^{\mathrm{es}}$, is carried out without pharmacological prophylactic or therapeutic means. A satisfactory control of pathologies is maintained, in fact, simply taking profit of the high microbial dilution in the open air, low density of the animals, avoiding direct contact and stamping out of suspected animals (Finzi, 2007).

In industrial rabbit farming, coccidiosis is wellcontrolled by using anticoccidials added to the feed (Gutiérrez, 2003; Coudert, 2004). However, in the alternative rabbit keeping system described, in which the feed is free of anticoccidials, little is known about the infestation levels of coccidia (Finzi et al., 1995). This research was carried out to determine the infestation levels by Eimeria comparing conventional and alternative rabbit keeping systems with different levels of hygienic control.

Sampling was done in four farms located in the Viterbo province (Italy) which had different levels of hygienic conditions, with specific reference to the cleanness of the cage floor. Two farms (A, B) raised hybrid rabbits and were industrial facilities, consisting in standard buildings with static ventilation, with control of the environmental microclimatic conditions, and separate housing for breeding and fattening. The other two farms $(\mathrm{C}, \mathrm{D})$ raised the breed Leprino di Viterbo (Finzi, 2007) and were open air alternative units based on the underground explorable cell system. Prophylaxis was done by stamping out of any suspected animal. The plastic slatted base platforms in the cages and in the underground cells were movable and easily substituted when dirty to be put in a 0.5 chlorine 
solution after each reproductive cycle. The farms were:

- Farm A. Intensive farm (650 does) in which the feed included an anticoccidial (Robenidine 66 ppm) in the case of does and kits for 10 days after weaning. The hygienic conditions were intermediate.

- Farm B. Intensive farm (1,000 does) in which the feed did not included anticoccidials. The feed for fattening rabbits included oxytetracycline $(500 \mathrm{~g} / \mathrm{qm})$ and zinc bacitracin $(150 \mathrm{~g} / \mathrm{qm})$ for epizootic rabbit enteropathy prophylaxis. The hygienic conditions were high.

- Farm C. Very small alternative unit (18 does) in which the feed did not included anticoccidials, and that had intermediate hygienic conditions.

- Farm D. Small alternative farm (54 does) in which the feed did not included anticoccidials, and that had high hygienic conditions.

In every farm, samplings were done in three groups of animals: does, kits 10-days after weaning (45 days aged) and rabbit at the end of the fattening period (70-90 days aged). Individual fresh faecal samples were collected in containers set under the cages or taken directly from the animals, and stored in polyethylene bags refrigerated at $4^{\circ} \mathrm{C}$ until examination by the flotation technique for the presence and counting of eimerian oocysts. Counts of coccidial oocysts per gram (OPG) in faeces were done using the Mc Master technique to assess the intensity of infestation (Gibbons et al., 2005). In order to analyse differences in oocyst excretion among farms and among groups of rabbits one-way analyses of variance were performed if the variables showed homogeneity of variance, and Kruskall-Wallis tests' if the variables showed heterogeneity of variance. In the analysis of variance, differences between the means were evaluated by the Duncan's test. The statistical analyses were performed using the SPSS 9.0 program (SPSS..., 1999).

In general terms, the parasitic status may be considered satisfactory (Table 1), given that in most cases there were less than 1,000 OPG (Coudert et al., 2000). The presence of oocysts was relatively low and the higher levels were observed in the does of farm $\mathrm{C}(\mathrm{P}>0.05)$ and in the weaned rabbits of farms $\mathrm{A}$ and $\mathrm{C}(\mathrm{P}<0.001)$, as to say when the hygienic conditions were not considered high, independently of the anticoccidial treatment (A) or not (C). In most cases not even one oocyst per sample was observed and only some subjects were sensibly infected. This explain why the coefficients of variability were rather high. In the farm A also the differences in excretion of oocysts among does, weaned and fattened rabbits was significant $(\mathrm{P}<0.001)$.

Table 1. Oocysts excretion (oocysts per gram; OPG) in four rabbit farms (F) according to age group, keeping system $(\mathrm{KS})$, and hygienic conditions (HC)

\begin{tabular}{|c|c|c|c|c|c|c|c|c|c|c|c|c|}
\hline \multirow[b]{2}{*}{$\mathrm{F}$} & \multirow[b]{2}{*}{$\mathrm{KS}$} & \multirow[b]{2}{*}{$\mathrm{HC}$} & \multicolumn{3}{|c|}{ Does } & \multicolumn{3}{|c|}{ Kits 10 -day after weaning } & \multicolumn{3}{|c|}{ Fattening rabbits } & \multirow[b]{2}{*}{$\mathrm{P}$} \\
\hline & & & $\mathrm{N}$ & $\begin{array}{c}\text { average } \pm \\
\text { SE }\end{array}$ & $\begin{array}{l}\mathrm{CV} \\
(\%)\end{array}$ & $\mathrm{N}$ & $\begin{array}{c}\text { average } \pm \\
\text { SE }\end{array}$ & CV (\%) & $\mathrm{N}$ & $\begin{array}{c}\text { average } \pm \\
\text { SE }\end{array}$ & $\begin{array}{l}\mathrm{CV} \\
(\%)\end{array}$ & \\
\hline A & Conv & Inter & 20 & $\begin{array}{l}147.5 \pm \\
73.1 \mathrm{~b}\end{array}$ & 221.7 & 20 & $\begin{array}{l}13,490.0 \pm \\
4,502.7 \mathrm{aA}\end{array}$ & 149.3 & 20 & $\begin{array}{l}1,182.5 \pm \\
396.6 \mathrm{bA}\end{array}$ & 150.0 & $<0.001$ \\
\hline B & Conv & High & 27 & $\begin{array}{c}127.8 \pm \\
127.8\end{array}$ & 519.6 & 30 & $\begin{array}{l}345.0 \pm \\
198.3 \mathrm{~B}\end{array}$ & 314.9 & 30 & $\begin{array}{l}55.0 \pm \\
22.9 \mathrm{~B}\end{array}$ & 228.2 & 0.126 \\
\hline $\mathrm{C}$ & Alter & Inter & 10 & $\begin{array}{c}1,660.0 \pm \\
1,518.3\end{array}$ & 289.2 & 9 & $\begin{array}{l}4,844.4 \pm \\
1,995.6 \mathrm{~B}\end{array}$ & 123.6 & 10 & n.d. & n.d. & 0.216 \\
\hline D & Alter & High & 11 & $\begin{array}{c}63.6 \pm \\
58.8 \\
0.061\end{array}$ & 306.5 & 11 & $\begin{array}{l}13.6 \pm \\
9.7 \mathrm{~B} \\
<0.001\end{array}$ & 237.0 & 20 & $\begin{array}{c}125.0 \pm \\
109.8 \mathrm{~B} \\
<0.001\end{array}$ & 392.7 & 0.700 \\
\hline
\end{tabular}

Values in the same row with different lowercase letters differ $(\mathrm{P}<0.05)$.

Values in the same column with different uppercase letters differ $(\mathrm{P}<0.01)$.

Conv: conventional; Alter: alternative units based on the underground explorable cell system; Inter: intermediate; SE: standard error; n.d.: data not available; CV: Coefficient of variation.

It is well-known that suckling rabbits cannot be infested by coccidiosis prior to three-week of age (Pakandl and Hlásková, 2007). Adult rabbits, which are usually symptomless carriers of coccidial infestation, serve as potential source of severe infestation for younger ones, specially after weaning (Coudert et al., 2000). This explains why in the farms $\mathrm{A}$ and $\mathrm{C}$, whose hygienic conditions were intermediate compared 
to the another farms, oocysts excretion by the weaned kits were high.

The best result observed in the alternative keeping unit D shows that the movable slatted floors are a very favourable condition since they are very easily removed and substituted, being efficiently disinfected. Another favourable point is that sore paws were never observed when the plastic slatted floor are utilised. In general terms, from 4,000-5,000 OPG it is advisable to apply medical prophylaxis (Coudert et al., 2000; Gutiérrez, 2003). Thus, due to the low level of oocysts excretion in the alternative farms of our study, in which no anticoccidials were used, the most important conclusion is the consideration that a fair control of hygienic conditions is sufficient to maintain a low level of coccidia, and that a pharmacological prophylaxis could be easily avoided in alternative keeping systems based on the underground explorable cell when high hygienic conditions are maintained.

Keywords: coccidiosis, non-pharmacological control, rabbit, unconventional keeping

\section{RESUMO}

Amostras fecais de coelhos foram examinadas pela técnica de flutuação para a presença e contagem de oocistos do gênero Eimeria, de acordo com a técnica McMaster, em uma investigação com o objetivo de comparar um sistema alternativo não medicamentoso de criação de coelhos e sistemas convencionais com diferentes níveis de controle higiênico. A presença de oocistos nas diferentes explorações foi baixa, mas muito variável. As maiores concentrações de oocistos foram encontradas nas explorações cujas condições higiênicas não foram boas, independentemente do tratamento ou não com anticoccidiano, ou do sistema de criação. Os melhores resultados foram observados no sistema alternativo com boas condições higiênicas. Neste sistema, a concentração de oocistos nos láparos desmamados, que deveriam apresentar máxima susceptibilidade à infecção por Eimeria, foi muito baixa. Estes resultados indicam que o estrito respeito às condições higiênicas é suficiente para o controle da coccidiose e que a profilaxia farmacológica poderia ser evitada sempre que fossem adotadas altas condições higiênicas so sistema criatório ao ar livre, baseado em células subterrâneas exploráveis (tocas).

Palavras-chave: coccidiosis, coelho, controle não farmacológico, criação alternativa

\section{REFERENCES}

COUDERT, P. Evaluation of the efficacy of Cycostat ${ }^{\circledR} 66 \mathrm{~g}$ against coccidiosis in fattening rabbits under controlled field conditions. In: WORLD RABBIT CONGRESS, 8., 2004, Puebla. Proceedings..., Puebla, 2004. v.B, p.512-519.

COUDERT, P.; LICOIS, D.; DROUET-VIARD, F. et al. Coccidiosis. In: ROSELL J.M. (Ed). Enfermedades del conejo. Madrid: MundiPrensa, 2000. v.II, p.219-234.

DALLE ZOTTE, A. Perception of rabbit meat quality and major factors influencing the rabbit carcass and meat quality. Livest. Prod. Sci., v.75, p.11-32, 2002.

DE LAZZER, M.J.; FINZI, A. Efficiency of three different housing systems in reducing heat stress in rabbits. In: WORLD RABBIT
CONGRESS, 5., 1992, Corvallis. Proceedings ..., Corvallis, 1992. v.B, p.745-750.

FINZI, A. Technical support to agricultural development and settlements in West Noubaria, Egypt. Technical report. Rome: FAO, 1987 (Project EGY/85/001).

FINZI, A. An unconventional rabbit-keeping system to produce high quality meat. In: CONFERENCIA INTERNACIONAL ECOLÓGICA EN EL SUR DE EUROPA, 1., 2004, Zamora. Proceedings..., Zamora, 2004. p.83-89.

FINZI, A. From food security to high quality meat: only one unconventional system. In: INTERNATIONAL CONFERENCE ON RABBIT PRODUCTION, 2007, Bogor. Proceedings..., Bogor: Indonesian Centre for Animal Research and Development y World Rabbit Science Association, 2007. 
FINZI, A.; CIORBA, P.; MACCHIONI, P. Rabbit does behaviour in choosing living area in the underground cell system. In: WORLD RABBIT CONGRESS, 7., 2000, Valencia. Proceedings..., Valencia, 2000. v.B, p.525-529.

FINZI, A.; MARGARIT, R.; MORDACCHINI ALFANI, M.L. Control tecnológico de la coccidiosis. In: SYMPOSIUM DE CUNICULTURA ASESCU, 20., 1995, Santander. Proceedings..., Santander, 1995. p.118-124.

FINZI, A.; MARIANI, G.; ALBANI, A. Producción cunícola de calidad. In: SYMPOSIUM DE CUNICULTURA ASESCU, 29., 2004, Lugo. Proceedings..., Lugo, 2004 (CD-ROM).

FINZI, A.; NYVOLD, S.; EL AGROUDI, M. Evaluation of heat stress in rabbits under field conditions. In: WORLD RABBIT CONGRESS, 5., 1992, Corvallis. Proceedings..., Corvallis, 1992a. v.B. p.739-744.

FINZI, A.; NYVOLD, S.; EL AGROUDI, M. Efficiency of three different housing systems in reducing heat stress in rabbits. In: WORLD RABBIT CONGRESS, 5., 1992, Corvallis.
Proceedings..., Corvallis, 1992b. v.B. p.745750.

GIBBONS, L.M.; JACOBS, D.E.; FOX, M.T. et al. McMaster egg counting technique. The RVC/FAO Guide to Veterinary Diagnostic Parasitology. 2004. Disponível em: $<$ http://www.fao.org/ag/AGAInfo/resources/doc uments/Parasitology/EggCount/Purpose.htm>. Accessado em: 15 Jul. 2007.

GUTIÉRREZ, J.F. Tratamientos y profilaxis de la coccidiosis en el conejo. Cunicultura, v.162, p.97-106, 2003.

PAKANDL, M.; HLÁSKOVÁ, L. The reproduction of Eimeria flavescens and Eimeria intestinalis in suckling rabbits. Parasitol. Res., v.101, p.1435-1437, 2007.

PEETERS, J.E.; GEEROMS, R.; HALEN, P.H. Epidemiology of coccidiosis in commercial rabbits (1982-1987) and resistance against Robenidine. In: WORLD RABBIT CONGRESS, 4., 1998, Budapest. Proceedings..., Budapest, 1988. v.1, p.399-408.

SPSS 9.0. Manual del usuario. Chicago: SPSS Inc., 1999. 